\title{
HARMONIZATION OF SERBIAN COMPETITION POLICY IN BANKING SECTOR WITH EU REGULATIONS
}

\author{
Gordana Đuranović ${ }^{1 *}$, \\ Sanja Filipović ${ }^{2}$ \\ ${ }^{1} \mathrm{PhD}$ candidate, \\ Singidunum University, \\ Belgrade, Serbia \\ ${ }^{2}$ Singidunum University, \\ Belgrade, Serbia
}

\begin{abstract}
:
The existence of a legal framework for the protection of competition is "condicione sine qua non" for the modern market economy and fair market game in every industry. The purpose of this research is to analyze competition policy in the banking sector in Serbia and compare it with EU regulations to find out if the Serbian banking competition policy is aligned with EU standards. In this empirical research comparative analysis method has been applied. On the ground of received results, the empirical research shows that competition policy in the Serbian banking sector is moderately harmonized with EU rules.
\end{abstract}

Keywords:

competition, banking sector, Serbia, EU, concentration.

\section{INTRODUCTION}

Economic sanctions (1992-1996 and again in 1998), together with the NATO bombing in 1999, were the main reasons why the transition to market economy in Serbia lasted longer than in other Central Eastern European countries. Successful implementation of the transition process has required designing of legal provisions adequate for the operating of a market economy. One of the most significant steps in that process has been the introduction of market competition, including the demonopolization of highly concentrated economies and expansion of the private sector in the economic activity.

The first law to regulate the behavior of market participants was the Federal Anti-monopolistic Law adopted in 1996 (Protić \& Lazarević, 2017). Although this Law prohibited the abuse of a dominant and monopolistic position, it lacked the definition of concentrations and did not recognize the category of entry and exit impediments and the difference between real and potential competition. Besides, the Anti-monopoly Commission was set up as an administrative body within the Federal Ministry of Economy and Internal Trade. Having in mind all these shortcomings, the new Law on Protection of Competition was adopted in 2005, while the Commission for the Protection of Competition was set up as an independent and autonomous organization body (Penev \& Filipović, 2008). As a result of further harmonization with the EU regulations, the currently in force Law on the protection of competition (Official Herald of the Republic of Serbia, No. 51/2009 and 95/2013) was adopted in 2009. On the other hand, harmonization with the EU

Correspondence: Gordana Đuranović

e-mail: gordana.zezelj.11@singimail.rs legislation and the reform of the Serbian banking sector began in 2001 with the adoption of the Bank Restructuring strategy followed by the Bank Privatization Strategy, as well as the accompanying Laws (Filipović, 2003). 
The purpose of this research is to analyze the competition policy in the banking sector in Serbia and compare it with EU regulations to examine whether it is harmonized with EU standards.

\section{LITERATURE REVIEW}

Competition policy in banking and the effects that it causes are the subject of many research studies. Gelos and Roldos (2002) investigated the evolution of market structure in emerging market banking systems during the 1990s on a sample of 8 European and Latin American countries and proved that the reduction in the number of banks in observed countries has not been systematically associated with the increased concentration as measured by standard indices and that banking markets have not become less competitive.

Claessens and Laeven (2003) performed a research of banks in 50 countries and found that competition increased with restrictions on (foreign) bank's entry on the market and that there is no evidence that competitiveness was measured negatively related to the banking system concentration.

Casu and Girardone (2009) measured the level of competition in the biggest five EU banking markets (Germany, Italy, France, Spain, and the UK) in the period from 2000-2005 applying structural (concentration ratios and Herfindahl-Hirshman Indices) and non-structural (H-statistics and Lerner Index) approach. The outcome showed a steady increase in concentration degree, which is not connected to the level of competition.

Maudos and Vives (2019) investigated the development of competition in the EU banking sector and found that competition decreased after the adoption of the euro as a common currency and digitalization, but keeping competitiveness intensive can increase it in the future.

Beck et. al. (2004) investigated the influence of bank concentration on banking system fragility on the crosscountry data in 69 countries and 47 crisis episodes. The research confirmed that concentration and competitiveness of the banking sector are connected with banking stability. The same year, Berger et. al. (2004) proved on an example of 14,000 banks in 72 countries that legal impediments to bank competition are connected with a lower demand for loans, less acceptable prices and instability of the financial system. Generally, proceedings that restrict bank competition provisions, impediments to foreign bank operations, and direct state control of banking resources, negatively influence economic activity.

As a result of research of sixty reports and a series of tables on concentration trends in a number of industries and market structures in member countries of the Commission of the European communities (today's EU), we can conclude that causes and effects of concentration are to be found in the structure, performance and competitive strategy of the individual firm (Linda, 1976).

Banking competition policy in Serbia, development and harmonization with EU legislation were also the subject of scientific papers. Barjaktarović (2010) considered that competitiveness in the banking sector should be reached by improvement of service quality, permanent competence development, adequate motivation system of employees, innovation, improvement of leadership and management skills, flexible organizational structure and modern technology. The research of Barjaktarović et. al (2014) shows that implemented legislative framework influenced both the capital level and capital adequacy level beyond the level proposed by the Basel framework (19.87\% in Serbia, $8-12 \%$ in EU) and reveals that the growing number of banks are investing in IT and staff training with the aim of efficient implementation of Basel standards and better risk management.

\section{EU ACQUIS COMMUNAUTAIRE AND COMPETITION POLICY}

The borders of the EU limit the territorial scope of application of the EU legislation, but in exceptional cases, the "acquis" can be applied outside the EU, which is most often the case with the competition law.

Competition in the European banking sector has evolved from 1992 till nowadays with the banking regulations, the implementation of the euro in 1999, and the recession. The most important regulations are: the Second Banking Directive, the Financial Services Action Plan (1999-2005) and the Basel agreements, international one risk-based capital standard, as a capital adequacy ratio which shows the ratio of capital and risk weighted assets. Basel I was fully implemented in 1993 with amendments in January 1996. Basel II, was adopted in 2004 and entered into force in 2007. In 2010 Basel III was adopted, to improve the ability of banks to absorb shocks arising from the environment, increase the transparency of banks and establish adequate regulatory frameworks (Todorović \&Tomić, 2020). The European Banking Authority (EBA) is responsible for the implementation of competition rules, together with the Capital Requirements Regulation (CRR) and Directive (CRD) (European Banking Authority, 2021). After the Basel agreements, the Single Supervisory Mechanism and the Single Resolution Mechanism were added to the list of EU competition regulations in 2014 and 2015, respectively.

The European Commission (EC) is the EU authority responsible for the competition policy and application of rules to provide fair market game among all market participants. 
The Directorate-General for Competition (DG COMP) implements the EU competition rules under the EU Treaties. The EC did not use Articles 85 and 86 of the Rome Treaty (which are currently Articles 101 and 102 of the Treaty) for the banking sector until 1981 when the European Court of Justice (ECJ) decided that competition policy is applicable to credit institutions.

Competition Policy instruments are antitrust, cartels, mergers, and state aid regulations. Antitrust is regulated by Articles 101 and 102 of the Treaty that forbid agreements that limit competition and the abuse of dominance on an observed market. Cartels are also prohibited agreements of a group of autonomous legal entities, which unite to adjust prices and production and divide among themselves the market and customers. Their nature is secret, so it is very difficult to detect them and prove them, which caused the creation of a very effective weapon against them - leniency program. This legal solution implies immunity from penalties for companies that share significant information about other members of the cartel they are involved in (European Commission, 2021).

Some mergers can jeopardize competition and announced acquisitions have to be investigated to avoid negative impact on competition.
Beside the EC, according to the European Merger Regulation (Article 21), member States can prohibit a merger to save financial stability in the domestic market. When it comes to state aid, it is generally prohibited unless it is in line with the EU regulations and if it is significant for economic development, because it puts the company in a privileged position.

The European Central Bank (ECB) has published the annual report valid for 2020, for the banking sector in the $\mathrm{EU}$, which includes staff and branches statistics as well as data on the level of concentration of the banking sector for every country, and data on foreign-controlled institutions in each Member state. The decline of $-2.28 \%$ to $-30.66 \%$ in the number of bank branches in the EU, in 24 from 27 countries, was observed (the total number was 143,158); as well as in the number of employees of credit institutions in 22 member countries with an average drop of $1.55 \%$. The average concentration level in the banking sector measured by the share of assets held by the five biggest banks in every member country was $67.25 \%$ at the end of 2020 (European Central Bank, 2021). Figure 1 represents the total assets of credit institutions headquartered in the EU in billions EUR at the end of March 2021.

Figure 1. Total assets of credit institutions headquartered in the EU

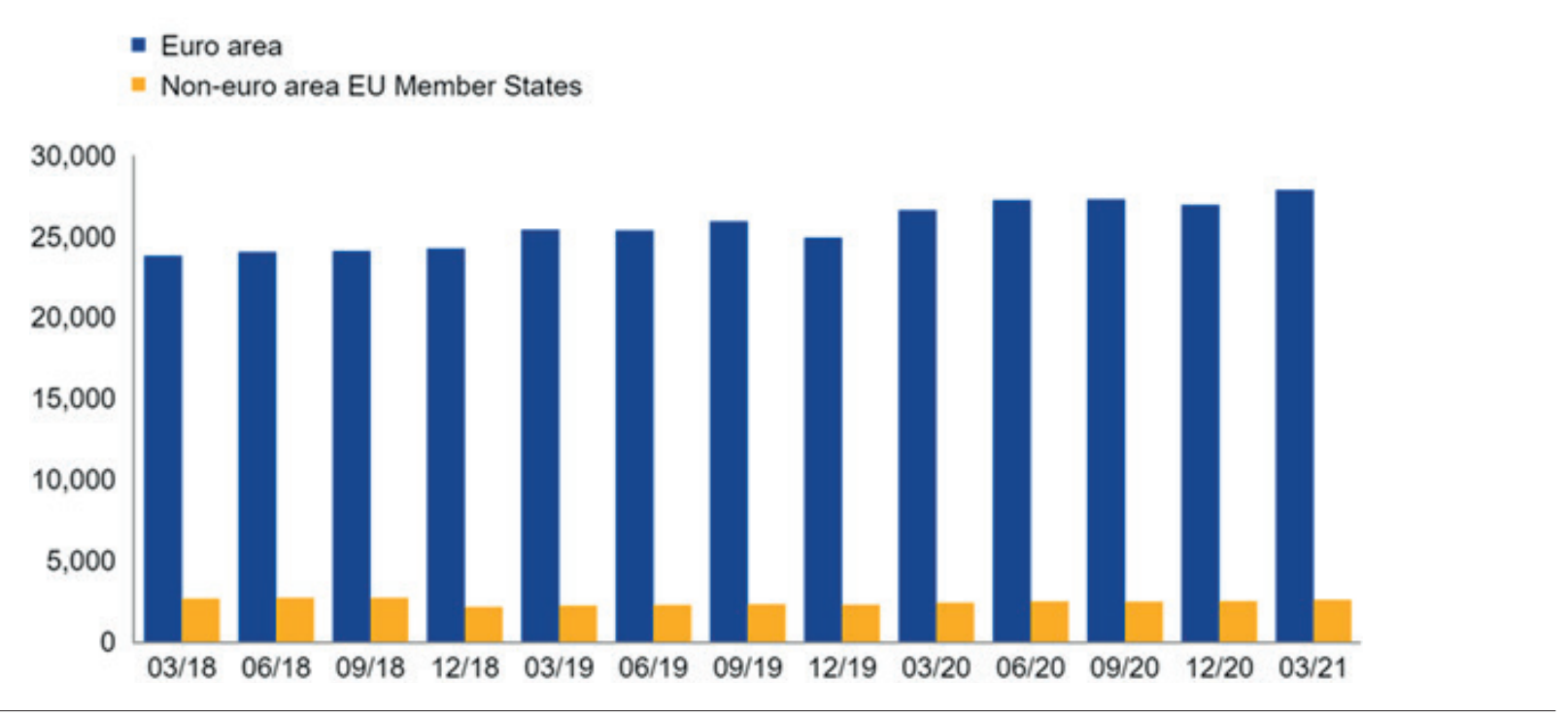

Source:ECB

\section{HARMONISATION OF SERBIAN COMPETITION REGULATORY FRAMEWORK WITH EU REQUIREMENTS}

The Serbian Law on the Protection of Competition adopted in 2009, with bylaws ( adopted in 2009 and 2010) and amendments (2013) has been aligned with the Council Regulation (EC) No 1/2003 of 16 December 2002 on the implementation of the rules on competition laid down in Articles 81 and 82 of the Treaty.
The legal aim of this document is the application of competition regulations in order to further harmonize this area with the EU's and domestic regulations and it is fully compliant with the following legislation:

- Council Regulation (EC) 139/2004 on the control of concentrations between entrepreneurs

- Commission Regulation (EU) 330/2010 on the application of Article 101 paragraph three of the Treaty on the Functioning of the European Union into categories of vertical agreements and harmonized practices; 
- Commission Regulation (EC) 773/2004 laying down procedures for The Commission conducts on the basis of Articles 81 and 82 of the EC Treaty;

- Commission Regulation (EC) No 802/2004 implementing the Regulation Council (EC) $139 / 2004$ on the control of concentrations between undertakings;

- Commission Regulation (EU) 1217/2010 and 1218/2010 on the application of Article 101 paragraph 3 of the Treaty on the Functioning of the European Union into certain categories research and development agreements and certain categories of specialization agreement;

- Commission Notice on the definition of the relevant market for legal purposes Competition Communities (97 / C 327/03); Commission Notice on Immunity from Punishment and Reduction of Fines in cartel cases (OJ C 298/17);

- Instructions on how to impose penalties in accordance with Article 23 (2) (a) of the Regulation1/2003 (2006 / C 210/02);

- Notification to the Commission of agreements of minor importance which do not restrict competition significantly in accordance with Article 101 (1) of the Treaty on the functioning of the EU. (Protić \& Lazarević, 2017).

This Law takes over the formulation of restrictive agreements from Article 101, paragraph 1 of the Treaty on the functioning of the EU (TFEU), as it is written in Article 10 of the Law. Abuse of dominant position is prohibited by this Law and regulated in Article 16, which takes over the provision of Article 102 TFEU. Investigation of concentration ex officio is defined in Article 62 saying that upon learning of implemented concentration, the Commission may investigate the concentration if it finds that the market share of legal entities who are taking part in the concentration is $40 \%$ or more and if the conditions from Article 19 regarding permissibility are not met. If the Commission determines the competition infringement or other law injury, it shall impose a measure for the protection of competition, measure to eliminate competition infringement or other administrative measure prescribed by the Law. In 2016, one of the amendments to the Criminal Code reforms the provisions on the criminalization of cartels. Pursuant to Article 229, in case of conclusion of a restrictive agreement, the court may impose a sentence of imprisonment from 6 months to 5 years and a fine. (Criminal Code, Official Herald of the Republic of Serbia No. 85/2005, 88/2005, 107/2005, 72/2009, 111/2009, $121 / 2012,104 / 2013,108 / 2014,94 / 2016$ and 35/2019).
Analyzing the legal framework for the protection of competition in the banking sector, it is important to highlight the Law on the National Bank of Serbia (NBS). Article 7 of this Law sets forth that the law on the protection of competition should apply to the competition on the banking market. According to this Law, Article 133, paragraph 3, along with the application specified in paragraph 1 thereof, there is a list of documents that the bank that initiated the takeover is obligated to deliver to the NBS ( The Law on the National bank of Serbia, Official Herald of the Republic of Serbia, No 72/2003, 55/2004, 85/2005, 44/2010, 76/2012, 106/2012, 14/2015, 40/2015 - constitutional court decision, and 44/2018).

The EC's annual report on the accession of the Republic of Serbia to the EU for 2020 states for Chapter 8 (Competition policy) and Chapter 9 (Financial services) that the good level of progress is achieved and it can be said that Serbian regulations are moderately harmonized with the European competition policy. The adoption of the new Law on State Aid Control in 2019 has established a wider operational scope of activities and more autonomy to the Commission for Protection of Competition. When it comes to antitrust and mergers, the legislation is compliant with the provisions of the Stabilisation and Association Agreement (SAA). The Commission for Protection of Competition as the main authority had a lot of antitrust cases, but did not forbid any merger, although it imposed two sentences. In 2016, the new Regulation on the content and manner of filing a notification of a concentration was adopted (Regulation on notification of a concentration). In December 2020, the Law on the Digital Property was adopted, which, for the first time in our country, regulates business related to virtual currencies. On the other hand, improvements of the Law on multilateral interchange fees and special operating rules for card-based payment transactions are still missing (European Commission, 2021).

When it comes to Chapter 9 - Financial services, there were a lot of activities in adjusting the legal framework:

- The Law on open-end investment funds with a public offering and the law on alternative investment funds have been adopted (bylaws are yet to be adopted);

- Adoption of the plan for implementing the directive on insurance distribution (April and December 2019) and amendments to the law on pension and disability insurance;

- Moratorium on all repayments under bank loans and financial leasing agreements as the NBS measure to preserve financial stability caused by the coronavirus crisis;

- Successful implementation of the International Financial Reporting Standards (IFRS) 9; 
- Adoption of the amendments to the Law on deposit insurance in 2019, with a significant change in the coverage level from EUR 50000 to EUR 100000 per depositor per bank(European Commission, 2021).

There is a need for the establishment of regulations in the field of compulsory traffic insurance and harmonization of the rules with the Solvency II directive. Also, there is no progress in developing financial infrastructure. Harmonization of domestic regulations with the new version of the EU Bank Recovery and Resolution Directive and with the Directive on the Activities and Supervision of Institutions for Occupational Retirement Provision in the fields of cross-border operations and investment and technical provisions regulation is not finished. The planned adoption of amendments to align the capital market law with the Markets in Financial Instruments Directive (MiFID II) and the Directive on Settlement Finality in Payment and Securities Settlement Systems (SFD), are delayed for the third quarter of 2021 (European Commission, 2021).
Among the last activities on the alignment with EU standards is the project "Further Development of Protection of Competition in Serbia" which was realized under the Twinning initiative launched by the EC to assist candidate countries in their efforts to strengthen their administrative and judicial capacity for the implementation of EU regulations ( www.kzk.gov.rs, 2021)

At the end of the fourth quarter of 2020, 26 banks mostly with foreign private capital were operating in the Serbian market. The biggest market share belongs to Banca Intesa ad (15\%), Unicredit bank ad (12\%) and Komercijalna Banka ad (10\%). Table 1 shows the shares of leading banks in the assets, loans and deposits of the Serbian banking sector (in \%) at the end of 2019 and 2020.

Table 1. Shares of leading banks in the assets, loans and deposits of the Serbian banking sector (in\%)

$31^{\text {st }}$ December 2019

$31^{\text {st }}$ December 2020

\section{Participation in assets in total}

\begin{tabular}{lll}
\hline First Bank & 16.0 & 15.6 \\
\hline First five banks & 53.4 & 52.5 \\
\hline First ten banks & 79.7 & 79.6 \\
\hline Participation in gross loans & 15.7 & 15.7 \\
\hline First Bank & 52.0 & 51.0 \\
\hline First five banks & 78.8 & 77.9 \\
\hline First ten banks & & 16.3 \\
\hline Participation in deposit potential & 17.2 & 53.1 \\
\hline First Bank & 54.9 & 80.4 \\
\hline First five banks & 81.2 & \\
\hline First ten banks & & \\
\hline
\end{tabular}

Source: NBS - annual report

As shown in table 2, according to the NBS data, the Serbian banking market in 2019 and in 2020 has a low degree of concentration and there is no threat to healthy competition.

Table 2. Degree of concentration (HHI)

\begin{tabular}{cccc}
\hline & Assets & Gross loans & Deposit potential \\
\hline $31^{\text {st }}$ December 2019 & 800 & 789 & 840 \\
\hline $31^{\text {st }}$ December 2020 & 786 & 783 & 809 \\
\hline
\end{tabular}

Source: NBS - annual report 


\section{CONCLUSIONS}

The aim of this research is to determine whether the Serbian competition policy in the banking sector is in line with EU regulations, comparing the Serbian legal framework with EU requirements. In the annual report for 2020, the EC rated the implementation of EU regulations for Chapter 8 and Chapter 9 as moderate, declaring that in the field of protection of competition and financial services Serbia had made good progress, and gave some recommendations for further actions in the process of alignment with EU legislation.

It can be concluded that in the state of strong competition in Serbia, the legal framework and banking policy are moderately harmonized with EU regulations, but for further improvement, some preconditions must be met.

First, the political-legal framework has to be adjusted to resolve the problem of the application of competition rules, implementation of adopted procedures and eradicate corruption. There is also a necessity for the more precise separation of judicial and executive power in general. Furthermore, for the stimulation of economic activity that can increase competition, additional tax reliefs for domestic investors and simplifying market entry for foreign investors, have to be considered. The adoption of the new Law on Protection of the Competition with bylaws is also very important, as well as the inclusion of the Commission for Protection of Competition in legislative activity in this area.

After creating a favorable political and legal environment, the most important is the policy of human resources: careful selection, development, education and training of the staff involved in the processes, especially in the Commission for Protection of Competition and in other institutions. Human capital is a key ingredient for full harmonization of competition policy in the Serbian banking sector, together with the promotion of the importance of competition policy, culture and raising understanding of it.

Further research should focus on the impact of the implementation of EU regulations on the development of competition in Serbia applying competition measures, as well as on the investigation of the interaction between the consolidation of banks and competition.

\section{LITERATURE}

Antimonopoly Law, (Official Gazette of the FRY, No. 29/96).

Barata, M.A. \& Smoleńska, A. (2017). EU competition policy in the European Banking Union - are the good old policies good enough? Available at: http://financial-stability.org/eu-competition-policy-in-the-european-banking-union-are-the-good-old-policies-good-enough/ (14.09.2021)

Barjaktarović L., Pindžo, R. \& Vjetrov, A. (2014). Analysis of the harmonization of the regulation related to the banking sector in Serbia with EU legislative framework. Available at: https://mfin.gov.rs/upload/media/ xYOzTH_6017e4637aba6.pdf (20.09.2021).

Barjaktarović, L. (2010). Konkurentnost u bankarskom sektoru Srbije, https://www.researchgate.net/publication/259901864_Konkurentnost_u_bankarskom_sektoru_Srbije/link/56c3393f08ae602342507f91/download

Beck, T., Demirgüç-Kunt, A. \& Levine, R. (2004). Bank Concentration, Competition, and Crises: First results. Journal of Banking \& Finance 30(5):1581-1603. Available at: https://www.researchgate.net/publication/4965031_ Bank_concentration_competition_and_crises_First_results (14.09.2021)

Berger, A., Demirguc-Kunt, A., Levine, R. \& Haubrich, J. (2004). Bank concentration and competition: An evolution in the making. Journal of Money, Credit and Banking, 36(3), 433-451.

Claessens, S. \& Laeven, L. (2003). What Drives Bank Competition? Some International evidence. The World Bank-Financial Sector Operations and Policy Department. Available at: https://elibrary.worldbank.org/doi/ abs/10.1596/1813-9450-3113 (06.09.2021.)

Council Regulation (EC) No 1/2003 of 16 December 2002 on the implementation of the rules on competition laid down in Articles 81 and 82 of the Treaty (Text with EEA relevance). Available at: https://eur-lex.europa.eu/eli/ reg/2003/1/oj (06.09.2021.)

Criminal Code, Official Herald of the Republic of Serbia, No. 85/2005, 88/2005., 107/2005., 72/2009., 111/2009., 121/2012., 104/2013., 108/2014., 94/2016. and 35/2019.)

European banking authority (2021). Implementing Basel III in Europe. Available at: https://www.eba.europa.eu/ regulation-and-policy/implementing-basel-iii-europe (14.09.2021.)

European Central Bank (2021). Annual report. Available at: https://www.ecb.europa.eu/ecb/html/index.en.html (06.09.2021.)

European Commission. (2005). White Paper on Financial Services Policy 2005-2010 (SEC (2005) 1574). Commission Staff Working Paper Document, Brussels. Available at: http://www.europarl.europa.eu/meetdocs/2004_2009/ documents/com/com_com(2005)0629_/com_ com(2005)0629_en.pdf (06.09.2021.) 
European Commission (2021). Commission staff working document, Republic of Serbia Report for 2020 which accompanying Communication from the Commission to the European Parliament, the Council, the European Parliament, the Economic and Social Committee and the Committee of the Regions Communication on the EU enlargement policy for 2020. Available at: https:// ec.europa.eu/neighbourhood-enlargement/sites/default/ files/serbia_report_2020.pdf (14.09.2021.)

European Commission. (2021). Competition policy. Available at: https://ec.europa.eu/competition-policy/index_en (14.09.2021).

Filipovic, S. (2003). Reform in the commercial banking sector. Available at: https://www.researchgate.net/publication/277137336_Reform_in_t:he_commercial_banking_sector (06.09.2021)

Gelos, R. Gaston, \& Roldos J. (2002). Consolidation and market structure in emerging market banking systems. IMF Working Paper, WP/02/186. Available at: https://www.elibrary.imf.org/downloadpdf/ journals/001/2002/186/001.2002.issue-186-en.pdf (14.09.2021.)

Guidelines on the assessment of horizontal mergers under the Council Regulation on the control of concentration between undertakings, SLC31/03,2004. Available at: www. europa.eu.int. (14.09.2021.)

Komisija za zaštitu konkurencije (2021). Dalji razvoj zaštite konkurencije u Republici Srbiji. Završna konferencija Twininig projekta - saopštenje za javnost. Available at: https://www.kzk.gov.rs/zavrsna-konferencija-tvinigprojekta (20.09.2021.)

Law on banks (Official Herald of the Republic of Serbia", No 107/2005, 91/2010 and 14/2015.)

Law on National bank of Serbia (Official Herald of the Republic of Serbia", No 72/2003, 55/2004, 85/2005, 44/2010, 76/2012, 106/2012, 14/2015, 40/2015 - constitutional court decision, and 44/2018.)

Law on protection of competition (Official Herald of the Republic of Serbia, No. 51/2009 and 95/2013)

Linda, R. (1976). Methodology of concentration analysis applied to the study of industries and markets. Commission of the European communities. Available at https:// core.ac.uk/download/pdf/5091475.pdf (20.07.2021.)

Maudos, J. \& Vives, X. (2019). Competition policy in banking in the European Union. Review of Industrial Organization, Springer. The Industrial Organization Society, 55(1), 27-46.

OECD. (2010). Competition, Concentration and Stability in the Banking Sector. Available at: https://www.oecd.org/ daf/competition/sectors/46040053.pdf

Penev, S. \& Filipović, S. (2008) Evaluation of competition policy and law in Serbia: Why do countries adopt new competition laws. Ekonomika preduzeća, vol. 56, iss. 3-4, pp. 133-143.
Protić, D. \& Lazarević, N. (2015). Politika konkurencije u Srbiji-u čemu je problem?, Centar za evropske politike, $p$. 16-21. Available at: https://www.cep.org.rs/images/efb_ competition/policy_study_politika_konkurencije_u_srbiji.pdf on 14.09.2021.

Todorović, V. \& Tomić, N. (2020). Bazelski sporazumi i stabilnost bankarskog sistema. Available at: https://www. researchgate.net/publication/344202344_BAZELSKI_ SPORAZUMI_I_STABILNOST_BANKARSKOG_SISTEMA (20.09.2021)

Treaty of the functioning of the EU. (2012). Official Journal C 326, 26/10/2012 P. 0001 - 0390. Available at: https:// eur-lex.europa.eu/eli/treaty/tfeu_2012/oj (14.09.2021.)

Vlada Republike Srbije, Ministarstvo za evropske integracije. (2017). Pregovaračka pozicija Republike Srbije za Međuvladinu konferenciju o pristupanju Republike Srbije Evropskoj uniji za poglavlje 9 „Finansijske usluge“. Available at: https://www.mei.gov.rs/upload/documents/pristupni_pregovori/pregovaracke_pozicije/pregovaracka_pozicija_PG_9.pdf ( 14.09.2021.) 